\title{
Source apportionment of biogenic contributions to ozone formation over the United States
}

Rui Zhang ${ }^{1+}$, Alexander Cohan ${ }^{2}$, Arastoo Pour Biazar ${ }^{3}$ and Daniel S. Cohan ${ }^{1 *}$

1. Department of Civil and Environmental Engineering, Rice University, Houston TX, USA 77005

2. Lake Michigan Air Directors Consortium (LADCO), Rosemont IL, USA 60018

3. The National Space Science Technology Center, University of Alabama in Huntsville, Huntsville AL, USA 35899

${ }^{+}$Now at Cooperative Institute for Research in the Atmosphere, Colorado State University, 3785 Laporte Ave, Fort Collins CO, USA 80521

*Corresponding author

E-mail address: cohan@rice.edu (D. Cohan) 


\section{ABSTRACT}

3 Vegetation is the leading emitter of volatile organic compounds (VOC), a key

4 ingredient for ozone formation. The contribution of biogenic VOC (BVOC) emissions to

5 regional ozone formation needs better quantification so that air quality regulators can

6 effectively design emission control strategies. One of the key uncertainties for modeling

7 BVOC emissions comes from the estimation of photosynthetically active radiation (PAR)

8 reaching canopy. Satellite insolation retrieval data provide an alternative to prognostic

9 meteorological models for representing the spatial and temporal variations of PAR. In

10 this study, biogenic emission estimates generated with the MEGAN and BEIS biogenic

11 emissions models using satellite or prognostic PAR are used to examine the contribution

12 of BVOC to ozone in the United States. The Comprehensive Air Quality Model with

13 Extensions (CAMx) is applied with Ozone Source Apportionment Technology (OSAT)

14 and brute force zero-out sensitivity runs to quantify the biogenic contributions to ozone

15 formation during May through September 2011. The satellite PAR retrievals are on

16 average lower than modeled PAR and exhibit better agreement with SCAN and

17 SURFRAD network measurements. Using satellite retrievals instead of modeled PAR

18 reduces BEIS and MEGAN estimates of isoprene by an average of 3\%-4\% and 9\%-12\%,

19 respectively. The simulations still overestimate observed ground-level isoprene

20 concentrations by a factor of 1.1 for BEIS and 2.6 for MEGAN. The spatial pattern of

21 biogenic ozone contribution diagnosed from OSAT differs from the brute force zero-out

22 sensitivity results, with the former more smoothly distributed and the latter exhibiting

23 peak impacts near metropolitan regions with intense anthropogenic $\mathrm{NO}_{\mathrm{x}}$ emissions.

24 OSAT tends to apportion less ozone to biogenics as BVOC emissions increase, since that

25 shifts marginal ozone formation toward more $\mathrm{NO}_{\mathrm{x}}$-limited conditions. By contrast, zero-

26 out source apportionment of ozone to biogenics increases with BVOC emissions. OSAT

27 simulations with BEIS show that BVOCs typically contribute 10-19\% to regional ozone

28 concentrations at nonattainment receptor sites during episode days. 
30 Keywords: biogenic emissions, photosynthetically active radiation (PAR), Ozone Source

31 Apportionment Technology (OSAT), CAMx, Ozone, Geostationary Operational

32 Environmental Satellite (GOES) 


\section{Introduction}

34 The national average ambient ozone concentration in the United States has decreased

35 by $22 \%$ since 1990 due to Clean Air Act (CAA) regulations of nitrogen oxides $\left(\mathrm{NO}_{\mathrm{x}}\right)$ and

36 volatile organic compounds (VOC) emissions (Simon et al. 2014). Air quality

37 improvement has been verified by long-term space observations (Duncan et al., 2013;

38 Lamsal et al., 2015). However, ozone continues to exceed regulatory limits in

39 nonattainment areas near major cities (https://ozoneairqualitystandards.epa.gov/

40 OAR_OAQPS/OzoneSliderApp/index.html\#). States with nonattainment areas are

41 required to prepare State Implementation Plans (SIPs) to demonstrate future ozone

42 compliance (EPA, 2014a). Correctly quantifying the contribution of different source

43 sectors to ozone formation is crucial for the development of effective emission control

44 strategies (Lefohn et al, 1998; Reitze, 2004; Cooper et al., 2015). Non-anthropogenic

45 sources such as wildfire (Jaffe and Wigder, 2012), stratospheric intrusion (Langford et al.,

46 2009; Lin et al., 2012) and biogenic emissions (Roselle et al., 1991; Pierce et al., 1998;

47 Mao et al., 2013) can influence the performance of anthropogenic control strategies.

48 BVOC emissions contribute $75 \%-80 \%$ of total U.S. VOC emissions in the

49 Environmental Protection Agency (EPA) 2011 National Emissions Inventory

50 (2011NEIv2) (EPA, 2015). The leading BVOC species, isoprene, reacts rapidly with

51 hydroxyl radicals to form ozone (Pierce et al., 1998; Zhang et al., 2000). The high ratio of

52 BVOC to total VOC emission makes BVOC emissions a significant contributor to

53 regional ozone concentrations, especially over the heavily forested Southeast U.S. (Fiore

54 et al., 2005; Mao et al., 2013; Park et al., 2013). Estimations of BVOC emissions are

55 subject to large uncertainty and are not well constrained by proxy concentrations (i.e.

56 formaldehyde) observed from space. Hence, estimates of isoprene emissions by different

57 biogenic emission models can vary more than a factor of two (Shim et al., 2005; Warneke

58 et al., 2010).

59 BVOC emission estimates depend on ambient temperature, land use categories,

60 emission factors associated with different plant functional type (PFT), leaf area index

61 (LAI), and the amount of radiation reaching the canopy known as photosynthetically

62 active radiation (PAR) (Lamb et al., 1993; Guenther et al. 2012). The most widely used

63 biogenic emissions models in U.S. regulatory modeling are the Biogenic Emission 
64 Inventory System (BEIS; Pierce et al., 1998; Bash et al., 2015), and the Model of

65 Emissions and Gases and Aerosols from Nature (MEGAN; Guenther et al., 2006;

66 Guenther et al., 2012). MEGAN tends to estimate more isoprene emissions than BEIS

67 and with different spatial patterns, mainly due to the difference in emission factor settings

68 and the algorithms to parameterize response to temperature and light (Pouliot and Pierce,

69 2009; Warneke et al., 2010; Kota et al., 2015; Wang et al., 2017). Several studies have

70 used satellite observations of clouds to infer solar radiation fields and replace

71 meteorological model generated estimates of PAR (Pour-Biazar et al. 2007; Carlton and

72 Baker, 2011; Sakulvanotvittaya et al. 2012; Zhang et al. 2017).

73 A variety of source apportionment techniques can quantify the contributions of

74 different emission sources to pollutant concentrations (Mcnally et al., 2009; EPA 2010;

75 EPA 2014b; Collet et al., 2014; Goldberg et al., 2016). Ozone Source Apportionment

76 Technology (OSAT) in the Comprehensive Air-quality Model with Extensions (CAMx,

77 Ramboll Environ 2015) tracks the contributions of different emission sectors, source

78 regions, as well as initial and boundary conditions to simulated ozone concentrations

79 (Ramboll Environ 2015). OSAT apportions ozone to $\mathrm{NO}_{\mathrm{x}}$ or VOC depending on which

80 precursor was the limiting factor of ozone production, as determined by the ratio of

81 hydrogen peroxide and nitric acid production (Dunker et al, 2002). By contrast, brute

82 force sensitivity analysis computes the change in ozone if a source is completely removed

83 (zero-out) or reduced by a specified percent. Due to nonlinearities, zero-out source

84 contributions do not necessarily sum to total ozone concentrations (Cohan and Napelenok, 85 2011).

86 This study applies OSAT and brute force sensitivity analysis in CAMx to examine the 87 contributions of BVOC emissions from different source regions to ozone in the

88 continental U.S. from May - September 2011. Source apportionment is conducted for

89 three BVOC datasets, generated by BEIS and MEGAN with satellite radiation inputs, and

90 by BEIS with radiation data from the prognostic meteorological model.

\section{2. Methodology}




\section{$95 \quad$ 2.1 BVOC emission estimates using satellite PAR}

96 PAR satellite products are processed at the University of Alabama in Huntsville

97 (UAH) based on the latest retrieval algorithm from Geostationary Operational

98 Environmental Satellite (GOES) visible imagery (Pour-Biazar et al., 2007; Pour-Biazar et

99 al., 2015; Zhang et al., 2017). UAH collaborates with the Infrared Measurements and

100 Water Vapor Studies Group (IR group) at the National Aeronautics and Space

101 Administration (NASA) Marshall Space Flight Center (MSFC) to generate and archive

102 several GOES derived products including cloud albedo, surface albedo and surface

103 insolation for use in meteorological and air quality models (Haines et al., 2003).

104 In this PAR parameterization scheme, a conversion factor CF is introduced to

105 represent the portion of incoming solar radiation (insolation) that is in photosynthetically

106 active wavelengths. The formulation for CF encapsulates the impact of cloud attenuation

107 and zenith angle (Pour-Biazar et al., 2015; Zhang et al., 2017) and has been validated

108 with the data provided by Pinker and Laszlo (1992) and Frouin and Pinker (1995).

109 Supplemental document File S1 provides more detail on the CF function formulation.

110 The raw PAR retrieval products are in the format of hourly gridded files with $4 \mathrm{~km}$

111 horizontal resolution and available with 13 snapshots from 11:45 GMT to 23:45 GMT

112 each day. The retrieval products cover most of the continental United States (CONUS)

113 except the Northwest corner of Washington State due to the projection (Pour-Biazar et al.,

114 2015). The raw satellite PAR products are mapped to U.S. EPA's national 12km

115 modeling domain (12US2) and are interpreted to integer hours using the spatial allocator

116 tool (https://www.cmascenter.org/sa-tools/). All other meteorological inputs used to drive

117 BEIS or MEGAN, such as soil moisture and temperature in the surface layer, wind speed,

118 and 24-hr accumulated rain, are derived from a U.S. EPA 2011 Weather Research

119 Forecast (WRF) simulation (EPA, 2014c).

120 Seven sites of direct continuous measurements of PAR in the Surface Radiation

121 Budget Network (SURFRAD) (http://www.esrl.noaa.gov/gmd/grad/surfrad/) as well as

12240 selected sites for incoming solar radiation observation from paired pyranometers at the

123 Soil Climate Analysis Network (SCAN) (http://www.wcc.nrcs.usda.gov/scan/) are used

124 for comparison during the simulation time in order to evaluate the PAR and insolation

125 retrieval products from the GOES satellite. 
126 Due to the inherent difference between BEIS and MEGAN in considering the

127 response of isoprene emission with sunlight in canopy (Pouliot and Pierce, 2009),

128 different treatments are used to swap the GOES insolation/PAR retrieval products with

129 default weather model radiation outputs. For MEGAN, since the parameterization has the

130 option to either use the generic PAR scaled from the weather model simulation for

131 incoming solar radiation (e.g. the output parameter 'RGRND' in WRF with the scaling

132 factor 0.5) or use satellite retrieved PAR (Guenther et al., 2006), the UAH’s PAR

133 products were directly used. For BEIS, the incoming solar radiation rather than PAR is

134 used as an input and is separated into direct and diffuse components (Pierce et al., 1998).

135 Therefore, the GOES insolation product is used in BEIS for consistency.

136 This study applies BEIS (v3.14; Pierce et al., 1998) with prescribed LAI information

137 for 230 land use categories in Biogenic Emission Landuse Database version 3 with $1 \mathrm{~km}$

138 resolution and the county-level vegetation speciation from the 1992 Forest Inventory and

139 Analysis database (Bash et al., 2016). MEGAN (v2.1; Guenther et al., 2012) is run with

140 LAI information from re-gridded 8-day averaged Moderate Resolution Imaging

141 Spectroradiometer (MODIS) MCD15A2 products for years 2003 to 2011

142 (http://lar.wsu.edu/megan/guides.html). MEGAN PFT settings follow the 16 PFT

143 classification scheme used in the community land model (CLM) version 4 with the

144 horizontal resolution 30 arc-seconds for year 2008 (Lawrence et al., 2011).

\subsection{WRF-SMOKE-CAMx simulation platform}

147 The ozone modeling platform for this study uses the CAMx model with

148 meteorological inputs from the Weather Research and Forecasting (WRF, Skamarock et

149 al., 2008) model, anthropogenic emissions from the Sparse Matrix Operator Kernel

150 Emissions (SMOKE, https://www.cmascenter.org/smoke/) model, and biogenic

151 emissions from BEIS or MEGAN to provide biogenic emissions. The domain setting

152 follows the US Environmental Protection Agency (EPA) Office of Air Quality Planning

153 and Standards (OAQPS) 2011 modeling platform (12US2; EPA, 2014a), covering

154 CONUS as well as portions of Canada and Mexico with 12-km horizontal resolution

155 (Figure 1). The modeling examines the 2011 ozone season with a 5-month simulation 
156 from May 1 to September 30. Table 1 outlines model configurations for each component 157 of the platform.

158 Meteorological modeling is performed with the Advanced Research WRF core

159 (WRF-ARW) version 3.4. Important physical module option selections in this study

160 include the Rapid Radiative Transfer Model for General Circulation Models (RRTMG)

161 scheme for shortwave and longwave radiation calculation, Asymmetrical Convective

162 Model version 2 (ACM2) scheme for planetary boundary layer (PBL), Pleim-Xiu scheme

163 for land surface model, Morris double moment scheme for microphysics module, and

164 Kain-Fritsch scheme with Ma and Tan (2009) trigger function for cumulus physics

165 module. Analysis nudging was performed above the PBL by assimilating corresponding

166 temperature, moisture and wind speeds from the 12km North American Mesoscale (NAM)

167 analysis database. Sea surface temperatures are initialized with a $1 \mathrm{~km}$ data set from the

168 Group for High Resolution Sea Surface Temperatures (GHRSST) (Stammer et al., 2003).

169 More details concerning the modeling configuration and processing are provided in the

170 Technical Support Document of EPA OAQPS (EPA, 2014c). The 2011 WRF

171 meteorological data has been extensively evaluated on a national scale and was found to

172 outperform previous meteorological modeling efforts (EPA, 2014c). In terms of the key

173 meteorological inputs to impact the biogenic emission estimates and ozone simulation

174 performance in this study, the surface temperatures are slightly underpredicted, except for

175 a slight overprediction in the early morning hours. Water vapor mixing ratios are

176 generally underpredicted in the central and western US and over-predicted in the eastern

177 states. Wind speeds are slightly overpredicted in the early morning and slightly

178 underpredicted in the evening and night, while precipitation is overestimated in elevated

179 terrain such as Northern California and the Pacific Northwest.

180 The U.S. EPA developed a national 2011 emission inventory as part of their 2011

181 modeling platform in support of the 2015 National Ambient Air Quality Standards

182 (NAAQS) for ozone (EPA, 2015). The 12US2 gridded emission inventory generated by

183 SMOKE is based on the 2011 National Emissions Inventory, version 2 (2011NEIv2).

184 The inventory uses hourly 2011 continuous emissions monitoring system (CEMS) data

185 for electrical generation units (EGUs) emissions, hourly onroad mobile emissions, and

1862011 day-specific wild and prescribed fire data. 
The host photochemical transport model used in this study is CAMx version 6.20 (Ramboll Environ 2015). CAMx is a 3D air quality model commonly used for attainment demonstrations (EPA, 2014b) and has been shown to perform well in previous applications (Baker and Scheff, 2007; Simon et al., 2012). The configuration of CAMx applied in this study is shown in Table 1. Clear sky photolysis rates and ozone columns for CAMx are obtained by processing NASA OMI ozone column satellite observations

193 (ftp://toms.gsfc.nasa.gov/pub/omi/data/ozone/Y2011/). Initial and boundary conditions

194 for CAMx are derived from a 2011 GEOS-Chem simulation with 2 by 2.5 degree 195 resolution and up to 38 vertical layers (Henderson et al., 2014). Global emissions are 196 based on Emission Database for Global Atmospheric Research (EDGAR) with EPA

197 regional improvements for U.S., Canada, Europe, Mexico, and Asia. A complete 198 description of the methodology and evaluation of the GEOS-Chem modeling can be 199 found in Henderson et al. (2014).

200 Modeling results of the 2011 ozone season including maximum daily 8-hour ozone 201 (MDA8), hourly nitrogen dioxide $\left(\mathrm{NO}_{2}\right)$ and hourly isoprene concentrations are evaluated 202 with monitoring data from the Air Quality System (AQS), a national database of ambient 203 air pollution including criteria pollutants and speciated particulates maintained by EPA 204 (https://www3.epa.gov/airquality/airdata/). A variety of statistical metrics including 205 mean observed, mean modeled, correlation coefficient (R), normalized mean bias (NMB), 206 normalized mean error (NME) and fractional bias (FB) are calculated at each available 207 monitor (see supplemental document File S2 for the definitions of those metrics).

\subsection{Ozone source apportionment setup}

210 OSAT is used to apportion ozone to its precursor source emissions. The 12US2

211 domain is segmented into 6 different source regions grouped by the geographic area

212 comprising the multi-jurisdictional organization regions; Western Regional Air

213 Partnership (WRAP), Central Regional Air Planning Association (CenRAP), Lake

214 Michigan Air Directors Consortium (LADCO), Visibility Improvement State and Tribal

215 Association of the Southeast (VISTAS), and Mid-Atlantic/Northeast Visibility Union

216 (MANE-VU). All other locations are classified as 'other' including portions of Mexico

217 and Canada. See Figure 1 for a map of the 12US2 source regions. 
Emissions are broken into 6 source sector categories for source apportionment;

219 electrical generation units (EGUs), non-EGUs (NEGU), area sources (AREA), on-road

220 mobile (ONROAD), off-road mobile (OFFROAD), and biogenic (BIOS). Area sources

221 include prescribed and wild fires. Marine and rail traffic emissions are grouped with off-

222 road mobile emissions.

223 In addition to tagging different emission regions and sectors, the impacts from

224 boundary conditions (lateral boundary and top boundary) as well as initial conditions are

225 also tracked with OSAT.

226 OSAT results are processed following the procedure recommended by EPA (2010).

227 In summary, daily 8-hour average contributions corresponding with MDA8 ozone

228 concentrations above the 2008 national ambient air quality standard (NAAQS) are

229 averaged together for an overall contribution count. We focus our ozone apportionment

230 analysis on the monitor with the highest 2010-2012 ozone design value within each of 22

231 ozone nonattainment areas(see Figure 1 and Appendix Table S1 for the detail locations).

232 In total 3 OSAT analysis runs are conducted each using different BVOC emission

233 estimates, namely the default EPA biogenic emission estimates from BEIS, biogenic

234 emission estimates from BEIS using satellite insolation retrievals, and biogenic emission

235 estimates from MEGAN using satellite PAR retrievals. Due to the limitation of available

236 computational resources, OSAT was not applied with the combination of MEGAN

237 biogenic emissions and WRF-based PAR. The impact of MEGAN relative to BEIS and

238 of WRF PAR relative to satellite-based PAR can be assessed from the three simulations

239 that were conducted.

\section{2.4Brute force emission perturbation simulation}

242 A set of brute force emission perturbation runs is conducted to calculate the direct

243 impacts of emission reductions for comparison with the OSAT results. In summary, three

244 groups of brute force runs are conducted. The first group of simulation removes all

245 biogenic VOC emissions. The second group of simulations scales down the U.S. BVOC

246 emissions estimates by 50\% either from default BEIS, BEIS with satellite insolation, or

247 MEGAN with satellite PAR. The last group of simulations removes the BVOC

248 emissions only from the LADCO region. 


\section{Results and Discussion}

\subsection{Insolation and PAR estimates from WRF and GOES}

Insolation and PAR estimates from the WRF model and GOES satellite are evaluated with corresponding hourly ground pyranometer measurements at SCAN and SURFRAD monitors. Table 2 summarizes performance across evaluation sites with the statistics calculated only during daytime when satellite retrievals have nonzero insolation values.

257 The satellite-based estimates of insolation and PAR outperform WRF in terms of R

258 values and index of agreement (IOA). The satellite data substantially reduce the overestimation bias of WRF for insolation, reducing NMB from 19\% to 7\%. For PAR, using the satellite retrieval instead of WRF reduces NMB from 24\% to 9\% and NME

261 from 35\% to 22\%. Spatially, the satellite retrievals achieve better agreement with 262 evaluation sites in the West and Midwest than in the Eastern U.S. (Figure 2). The NMB 263 values in California sites for insolation comparison are less than $10 \%$ while there exist a

264 few sites located in New England with NMB>40\%. The spatial pattern of UAH's

265 insolation/PAR retrieval products' error is consistent with the previous evaluations of 266 different time periods (Zhang et al. 2017) and may result from the limited capacity of the

267 current algorithm to correctly account for a highly heterogeneous distribution of

268 precipitable water on insolation (Pour-Biazar et al., 2015).

\subsection{Isoprene emission estimates from BEIS and MEGAN}

271 MEGAN estimates higher isoprene emission rates than BEIS over most regions.

272 Spatially, the two models show similar hotspots for isoprene emissions over the broadleaf

273 forests of the Southern U.S. and lower emission rates over the Midwest and Pacific

274 Northwest (Figure S1). BEIS shows a strong peak in emissions over Southern Missouri

275 and Northern Arkansas, while MEGAN shows a more widespread high emission "plateau”

276 over Southern states. The contrasting spatial patterns may be due to the different PFT

277 database usage (BELD4 versus CLM) and different parameterizations of the response of

278 isoprene to sunlight in the two biogenic models (Pouliot and Pierce, 2009). 
Figure 3 provides histograms comparing estimates of isoprene emissions as well as available PAR from the five OSAT source regions using different BVOC emission models with WRF-based or GOES-based PAR inputs. Isoprene emissions estimated with MEGAN are roughly a factor of 2 higher than estimates from BEIS, especially over the

283 heavily forested regions in VISTAS and CenRAP. Using satellite data leads to less 284 isoprene emissions on average than its counterpart cases using WRF incoming solar 285 radiation simulation. However, the BEIS isoprene estimates are less sensitive to the 286 change of radiation input than MEGAN (2\%-3\% change for BEIS isoprene and 9\%-12\% 287 change for MEGAN with the smallest change region in LADCO and the largest change 288 region in VISTAS). This greater sensitivity of isoprene emissions to sunlight in MEGAN 289 than in BEIS arises from differences in the algorithms used to parametrize PAR.

290 MEGAN uses PAR as a direct input to its multilayer canopy model while BEIS computes 291 direct and diffuse PAR based on input data for total incoming solar radiation at the top of 292 the canopy (Pouliot and Pierce, 2009). The algorithms lead MEGAN to assume lower 293 PAR than BEIS in the simulations conducted here.

\subsection{Ozone simulation performance using different BVOC emission} 296 estimates

Table 3 provides a summary of statistics for CAMx performance of hourly isoprene, $\mathrm{NO}_{2}$ and MDA8 ozone at available AQS network sites (see Figure 1 for locations) during summer 2011 for the three OSAT simulation cases using different biogenic emission configurations. The 'MEGAN_GOES' case on average over-estimates isoprene concentrations by a factor of 2.3. The over-estimation of ground isoprene concentration by the other two BEIS cases is much smaller with the NMB values $28 \%$ for case 'BEIS_EPA' and 29\% for case 'BEIS_GOES'. The CenRAP region (NMB=404\%) and WRAP region (NMB=401\%) have the most severe over-estimation for isoprene concentrations. This is probably due to MEGAN estimates of much higher isoprene emission rates than BEIS at the AQS evaluation sites over those two regions (see Figure S1). MEGAN over-estimates of ground isoprene concentrations have been found in other modeling studies (Ying and Krishnan, 2010; Carlton and Baker, 2011; Zhang et al., 2017; Wang et al. 2017). Use of GOES insolation data slightly improved model performance 
310 for ground-level isoprene on high ozone days (using $50 \mathrm{ppbV}$ for observed hourly ozone 311 as the threshold to calculate statistics).

312 CAMx model performance for hourly $\mathrm{NO}_{2}$ concentrations differs little among the 313 three simulation cases since the insolation inputs barely impact biogenic NOx emission

314 estimates. On average, the CAMx model overestimates the $\mathrm{NO}_{2}$ concentrations by $9 \%$ -

$31513 \%$ with NME around $75 \%$. This suggests that despite site-specific errors, any systemic 316 overestimation of $\mathrm{NO}_{\mathrm{x}}$ emissions by the emissions inventory is slight.

317 All three CAMx runs simulated ozone reasonably well with a high correlation $318 \quad(\mathrm{R}=0.74-0.75)$ and low bias (NMB=11\%-14\%) and error (NME=17\%-19\%). The change 319 in ozone is slight despite the large change in BVOC because ozone is NOx-limited over 320 most of the domain. In terms of national average performance, the CAMx cases with 321 biogenic emission using satellite data have slightly better ozone results than the WRF 322 case, decreasing the simulation bias from $14 \%$ to $11-12 \%$ and error from $19 \%$ to $18-19 \%$. 323 Case 'BEIS_GOES' has the best overall ozone performance of the three BVOC dataset 324 runs while the case 'MEGAN_GOES' has better model performance during episode days. 325 Spatially, the cases with BEIS emissions have better ozone performance for peak ozone 326 simulation in the Midwest while the MEGAN case has better ozone performance in the 327 Northeast and California (Figure 3).

\subsection{OSAT source apportionment}

330 Spatial distributions of the OSAT-derived contributions of biogenic VOC sources 331 from the six source regions to average MDA8 ozone are shown in Figure 4 for each of 332 the three biogenic simulations. The average magnitude of biogenic contribution to 2011 333 summer ozone varies from $2 \mathrm{ppbV}$ to $17 \mathrm{ppbV}$ with peak values in California and some 334 central states. Even though the VISTAS region has the largest BVOC emission rate in 335 the U.S. (Figure 2), its OSAT contribution to regional ozone formation is relatively 336 modest with the typical value 5-11ppbV. The CAMx OSAT algorithm attributes ozone 337 production to VOCs only when ozone forms under VOC-limited conditions (Dunker et 338 al., 2002). Ozone formation in the VISTAS region is typically $\mathrm{NO}_{\mathrm{x}}$-limited due to 339 intense BVOC emissions in the Southeast. Hence, CAMx OSAT attributes most of the 340 ozone in this region to $\mathrm{NO}_{\mathrm{x}}$ rather than VOCs. The modeling of $\mathrm{NO}_{\mathrm{x}}$-limited ozone 
341 conditions in the Southeast is consistent with OMI satellite observations of formaldehyde 342 and $\mathrm{NO}_{2}$ (Duncan et al., 2010).

343 OSAT results show that the majority of ozone impacts occur within the source region, 344 and that BVOC emissions from each region have modest impacts on downwind regions.

345 BVOC emissions from WRAP and CenRAP contribute up to 1-3 ppbV of ozone to some

346 locations in New England states. By contrast, prevailing wind conditions preclude

347 MANE-VU emissions from substantially influencing ozone in other regions during the 348 period simulated.

349 Figure 6 shows pie charts of ozone source appointment results at the nonattainment 350 receptor sites tracked by the 6 major source sectors (BIOS, EGU, NEGU, ROAD, 351 NONROAD, AREA) as well as boundary conditions (see Figure 1 and Table S1). Results 352 are presented for each of the three biogenic emission configurations. For all three OSAT 353 simulations, the impact from boundary conditions is diagnosed as the top contributor to

354 regional MDA8 ozone formation averaged for all the nonattainment sites over the episode 355 days (nearly 50\% in WRAP region and 22-30\% for the rest of US). Ozone source 356 contributions in most locations range from 17-30\% from onroad sources, $7-20 \%$ from 357 offroad sources, 5-8\% from area sources, 4-7\% from non-EGU point sources, and 1-11\% 358 from EGUs. Biogenic VOC sources on average contribute 10-19\% of regional ozone 359 formation with higher contributions in the VISTAS region and the lower contributions in 360 the WRAP region. The biogenic contributions presented here are in line with similar 361 studies that examine different regions in the United States (EPA 2010; Alpine

362 Geophysics, 2012; Collet et al., 2014; Goldberg et al., 2016).

363 For individual sites located in the Denver-Boulder-Greeley-Fort Collins-Loveland 364 nonattainment area, the BCON contribution reaches as high as $80 \%$ (see Table S2). This 365 reflects the importance of stratospheric ozone intrusions at some high altitude locations, 366 which was also reported in similar OSAT studies (McNally et al., 2009; EPA 2014b).

\section{$368 \quad 3.5$ Comparing OSAT and brute force source apportionments}

369 Figure 7 shows a map comparing average biogenic contribution to ozone formation 370 during summer of 2011 estimated with CAMx OSAT and brute force zero-out analysis 371 for the three BVOC emission cases. Spatially, OSAT produces a more smoothly 
372 distributed field of contributions with a peak value in the Midwest ( 14ppbV). Brute

373 force indicates sharper peaks in BVOC contribution to ozone around metropolitan

374 regions with intense anthropogenic $\mathrm{NO}_{\mathrm{x}}$ emissions. This study used the OSAT2 scheme

375 for ozone apportionment in CAMx, which allocate the net change in ozone to tracers

376 under NOx or VOC-limited conditions. The next version OSAT3 scheme adds the

377 capability to account for NOx recycling by tracking source attribution of nitrogen through

378 all forms of NOy (Yarwood and Koo, 2015). The NO titration effect may change Figure

3797 in which differences in the contributions become more apparent over high-NOx areas.

380 OSAT attributes less ozone to BVOC under the MEGAN case than the BEIS cases.

381 This counter-intuitive result occurs because the larger BVOC emissions from MEGAN

382 push ozone formation toward more $\mathrm{NO}_{\mathrm{x}}$-limited conditions, leading OSAT to attribute

383 more ozone to $\mathrm{NO}_{\mathrm{x}}$ rather than VOCs. OSAT considers marginal sensitivity of ozone,

384 which is $\mathrm{NO}_{\mathrm{x}}$-limited over most of the CONUS domain during summer afternoons.

385 By contrast, the zero-out analysis shows a much bigger contribution of BVOC in the

386 MEGAN case, since that case has more BVOC to zero out than BEIS. In each case,

387 zeroing out BVOC emissions pushes ozone toward VOC-limited conditions, contrasting

388 the mostly $\mathrm{NO}_{\mathrm{x}}$-limited marginal conditions considered by OSAT. In the LADCO region,

389 the contribution of BVOC to ozone is similar in the OSAT and zero-out analyses, as

390 shown in Figure S3. This is because isoprene is a smaller share of VOC in the LADCO

391 region than in most other regions.

392 The nonlinearity of brute force ozone response to BVOC is illustrated in Figure S2,

393 which compares ozone impacts from the zero-out and 50\% BVOC reduction cases. The

394 ozone impacts of zero out are far larger than double the impacts of the 50\%-case, since

395 ozone becomes increasingly VOC-limited as BVOC is reduced. More generally, the

396 nonlinear response of ozone to emissions means that ozone cannot be strictly apportioned

397 as a sum of zero-out contributions (Cohan and Napelenok, 2011). That hinders

398 comparisons with OSAT, which apportions all ozone one-to-one to a precursor emission

399 source or initial and boundary conditions.

400 Source contribution results can differ significantly between average conditions and

401 ozone exceedance days. This is an important point that needs to be considered when

402 formulating an ozone attainment strategy, since the standard is based on days with peak 
ozone. Each of the source apportionment methods with different BVOC emission

404 estimates shows an increasing role for BVOC on days with high ozone concentrations

405 (Figure 8). This is more pronounced for the zero-out impact, since high ozone days tend

406 to have warm and sunny conditions that enhance BVOC emissions. That leads ozone

407 formation on these days to be more $\mathrm{NO}_{\mathrm{x}}$-limited, which dampens the OSAT source

408 apportionment to BVOC. Zeroing-out BVOC more radically shifts the ozone formation

409 regime to conditions that are unrealistic for this domain.

\section{Conclusions}

412 In this study, the WRF-SMOKE-CAMx modeling platform is utilized with OSAT and 413 zero-out source apportionment to explore the contributions of biogenic emissions to

414 ambient ozone concentrations in nonattainment areas in the United States during summer

415 2011. Since BVOC emission estimates are sensitive to solar radiation and vary between

416 models, we apply two widely used BVOC emission models (BEIS and MEGAN) with

417 both modeled and satellite-observed radiation data.

418 Application of satellite insolation/PAR data reduces the under-prediction of clouds in 419 the prognostic weather model (i.e. WRF) and improves agreement with surface radiation 420 monitors. BEIS with the GOES insolation retrieval achieved the best performance for 421 simulating ground-level isoprene and ozone concentrations. MEGAN produced higher

422 estimates of BVOC emissions that tended to over-predict isoprene and ozone 423 concentrations.

424 OSAT and zero-out source sensitivity runs yielded different results for apportionment 425 of ozone to biogenic emissions. Spatially, the BVOC emission contribution to regional 426 ozone formation is relatively smoothly distributed in OSAT, whereas in the zero-out 427 analysis it exhibits peak impacts near NOx-rich metropolitan regions. During episode 428 days with higher BVOC emissions, OSAT tends to apportion less ozone to biogenics due 429 to the shift of marginal ozone formation more toward NOx-limited conditions. By 430 contrast, zero-out attributes more regional ozone formation to biogenic sources due to the 431 greater amount of BVOC to zero-out on those days. OSAT simulation results for the 432 BEIS_GOES case found that domain-wide biogenic emissions contribute an average of $43310 \%-19 \%$ of ozone formation at nonattainment receptor sites during ozone NAAQS 
434 exceedance episode days. The difference of ozone source apportionment resulting from 435 the choice of biogenic emission models (BEIS vs MEGAN) is far greater than the 436 difference resulting from the choice of PAR inputs (WRF vs GOES satellite-based PAR). 437 438 


\section{Acknowledgements}

441 This study was supported by funding from the NASA Air Quality Applied Sciences

442 Team. We also thank the EPA Office of Air Quality Planning and Standards (OAQPS)

443 group who provided the default meteorology, emission information, and boundary

444 conditions used in the 12km 12US2 domain to run CAMx simulations.

445 


\section{References}

447 Alpine Geophysics, (2012). OSAT modeling analysis: relative contribution of source

448 area/source category to selected downwind nonattainment monitors. Available at:

449 http://www.midwestozonegroup.com/files/AlpineGeophysicsOSATAnalysis.pdf

450 Bash, J.O., Baker, K.R. and Beaver, M.R. (2016). Evaluation of improved land use and 451 canopy representation in BEIS v3. 61 with biogenic VOC measurements in California.

452 Geoscientific Model Development, 9(6), p.2191.

453 Baker, K. and Scheff, P. (2007), Photochemical Model Performance for PM2.5 Sulfate, 454 Nitrate, Ammonium, and Precursor Species SO2, HNO3, and NH3 at Background

455 Monitor Locations in the Central and Eastern United States, Atmospheric Environment, 456 41, 6185- 6195.

457 Carlton, A.G. and Baker, K.R., (2011), Photochemical modeling of the Ozark isoprene 458 volcano: MEGAN, BEIS, and their impacts on air quality predictions, Environmental 459 Science \& Technology, 45(10), pp.4438-4445.

460 Cohan, D.S., Hakami, A., Hu, Y. and Russell, A.G. (2005), Nonlinear response of ozone 461 to emissions: Source apportionment and sensitivity analysis, Environmental Science \& 462 Technology, 39(17), pp.6739-6748.

463 Cohan, D.S., and Napelenok, S.L. (2011), Atmospheric response modeling for decision 464 support. Atmosphere, 2(3), 407-425. doi:10.3390/atmos2030407.

465 Colella, P. and Woodward, P.R. (1984), The Piecewise Parabolic Method (PPM) for Gas466 dynamical Simulations, Journal of Computational Physics, 54, 174-201.

467 Collet, S., Minoura, H., Kidokoro, T., Sonoda, Y., Kinugasa, Y., Karamchandani, P., 468 Johnson, J., Shah, T., Jung, J. and DenBleyker, A. (2014), Future year ozone source 469 attribution modeling studies for the eastern and western United States. Journal of the Air 470 \& Waste Management Association, 64(10), pp.1174-1185.

471 Cooper, O.R., Langford, A.O., Parrish, D.D. and Fahey, D.W. (2015), Challenges of a 472 lowered US ozone standard, Science, 348(6239), pp.1096-1097.

473 Crawford, J., Davis, D., Chen, G., Bradshaw, J., Sandholm, S., Kondo, Y., Liu, S., 474 Browell, E., Gregory, G., Anderson, B. and Sachse, G. (1997), An assessment of ozone 475 photochemistry in the extratropical western North Pacific: Impact of continental outflow 476 during the late winter/early spring, Journal of Geophysical Research: Atmospheres, 477 102(D23), pp.28469-28487. 
478 Duncan, B.N., Yoshida, Y., Olson, J.R., Sillman, S., Martin, R.V., Lamsal, L., Hu, Y., 479 Pickering, K.E., Retscher, C., Allen, D.J. and Crawford, J.H. (2010), Application of OMI 480 observations to a space-based indicator of NOx and VOC controls on surface ozone 481 formation. Atmospheric Environment, 44(18), pp.2213-2223.

482 Duncan, B., Yoshida, Y.,de Foy B., Lamsal, L.,Streets, D., Lu Z., Pickering, K. and 483 Krotkov, N. (2013), The observed response of Ozone Monitoring Instrument (OMI) NO2 484 columns to NOx emission controls on power plants in the United States: 2005-2011, 485 Atmospheric Environment, 81, 102-111,doi:10.1016/jatmosenv.2013.08.068.

486 Dunker, A.M., Yarwood, G., Ortmann, J.P., Wilson, G.M. (2002), Comparison of source 487 apportionment and source sensitivity of ozone in a three-dimensional air quality model, 488 Environmental Science \& Technology, 36, 2953-2964.EPA (US Environmental 489 Protection Agency) (2010), Air quality modeling technical support document: ozone 490 source apportionment application in support of the designation process for the ozone 491 NAAQS. Available at: https://www3.epa.gov/scram001/reports/EPA-454_R-10-005.pdf.

492 EPA (US Environmental Protection Agency) (2010), Air quality modeling technical 493 support document: Ozone source apportionment application in support of the designation 494 process for the ozone NAAQS. Available at:

495 https://www3.epa.gov/scram001/reports/EPA-454_R-10-005.pdf.

496 EPA (US Environmental Protection Agency) (2014a), Draft modeling guidance for 497 demonstrating attainment of air quality goals for ozone, PM2.5 and regional haze.

498 Available at: https://www3.epa.gov/ttn/scram/guidance/guide/Draft_O3-PM-

499 RH_Modeling_Guidance-2014.pdf.

500 EPA (US Environmental Protection Agency) (2014b), Policy assessment for the review 501 of the ozone national ambient air quality standards. Available at:

502 https://www3.epa.gov/ttn/naaqs/standards/ozone/data/20140829pa.pdf.

503 EPA (US Environmental Protection Agency) (2014c), Meteorological model 504 performance for annual 2011 WRF v3.4 simulation. Available at:

505 http://www.epa.gov/ttn/scram/reports/MET_TSD_2011_final_11-26-14.pdf.

506 EPA (US Environmental Protection Agency) (2015), Preparation of emissions inventories 507 for version 6.2, 2011 emission modeling platform. Available at:

508 https://www.epa.gov/sites/production/files/2015-

509 10/documents/2011v6_2_2017_2025_emismod_tsd_aug2015.pdf.

510 EPA (US Environmental Protection Agency) (2016), Air quality modeling technical 511 support document for the final Cross State Air Pollution Rule update, Available at: 
512 https://www3.epa.gov/airmarkets/CSAPRU/AQ\%20Modeling\%20TSD\%20Final\%20CS

513 APR\%20Update.pdf

514 Fiore, A.M., Horowitz, L.W., Purves, D.W., Levy, H., Evans, M.J., Wang, Y., Li, Q. and

515 Yantosca, R.M. (2005), Evaluating the contribution of changes in isoprene emissions to

516 surface ozone trends over the eastern United States. Journal of Geophysical Research:

517 Atmospheres, 110(D12), doi:10.1029/2004JD005485.

518 Frouin, R. and Pinker R.T. (1995). Estimating photosynthetically active radiation (PAR)

519 at the earth's surface from satellite observations, Remote Sensing of Environment, 51,

520 98-107.

521 Goldberg, D.L., Vinciguerra, T.P., Anderson, D.C., Hembeck, L., Canty, T.P., Ehrman,

522 S.H., Martins, D.K., Stauffer, R.M., Thompson, A.M., Salawitch, R.J. and Dickerson,

523 R.R. (2016), CAMx ozone source attribution in the eastern United States using guidance

524 from observations during DISCOVER - AQ Maryland, Geophysical Research Letters,

525 doi:10.1002/2015GL067332.

526 Guenther, A.B., Karl, T., Widinmyer, C., Palmer, P.I. and Geron C. (2006), Estimates of

527 global terrestrial isoprene emissions using MEGAN (Model of Emissions of Gases and

528 Aerosols from Nature), Atmospheric Chemistry and Physics, 6, pp3181-3210.

529 Guenther, A. B., Jiang, X., Heald, C. L., Sakulyanontvittaya, T., Duhl, T., Emmons, L. K.,

530 and Wang, X. (2012), The Model of Emissions of Gases and Aerosols from Nature

531 version 2.1 (MEGAN2. 1): an extended and updated framework for modeling biogenic

532 emissions. Geoscientific Model Development, 5(6), 1471-1492.

533 Haines, S.L., Jedlovec, G.J. and Suggs R.J. (2003), The GOES Product Generation

534 System. NASA Technical Memorandum, Marshall Space Flight Center.

535 Henderson, B.H., Akhtar, F., Pye, H.O.T., Napelenok, S.L., and Hutzell, W.T., (2014), A

536 Database and Tool for Boundary Conditions for Regional Air Quality Modeling:

537 Description and Evaluation. Geophysical Model Development, 7, 339-360.

538 Hudman, R.C., Jacob, D.J., Cooper, O.R., Evans, M.J., Heald, C.L., Park, R.J.,

539 Fehsenfeld, F., Flocke, F., Holloway, J., Hübler, G. and Kita, K. (2004), Ozone

540 production in transpacific Asian pollution plumes and implications for ozone air quality

541 in California. Journal of Geophysical Research: Atmospheres, 109(D23), 910,

542 doi:10.1029/2004JD004974.

543 Jaffe, D.A. and Wigder, N.L. (2012), Ozone production from wildfires: A critical review,

544 Atmospheric Environment, 51, pp.1-10. 
545 Kota, S. H., Schade, G., Estes, M., Boyer, D., and Ying, Q. (2015). Evaluation of

546 MEGAN predicted biogenic isoprene emissions at urban locations in Southeast Texas.

547 Atmospheric Environment, 110, 54-64.

548 Lamb, B., Gay, D., Westberg, H. and Pierce, T. (1993), A biogenic hydrocarbon emission 549 inventory for the USA using a simple forest canopy model, Atmospheric Environment, 550 Part A. General Topics, 27(11), pp.1673-1690.

551 Langford, A.O., Aikin, K.C., Eubank, C.S. and Williams, E.J. (2009) Stratospheric 552 contribution to high surface ozone in Colorado during springtime, Geophysical Research

553 Letters, 36(12), doi:10.1029/2009GL038367.

554 Lawrence, D.M., Oleson, K.W., Flanner, M.G., Thornton, P.E., Swenson, S.C., Lawrence, 555 P.J., Zeng, X., Yang, Z.L., Levis, S., Sakaguchi, K. and Bonan, G.B. (2011),

556 Parameterization improvements and functional and structural advances in version 4 of the 557 Community Land Model. Journal of Advances in Modeling Earth Systems, 3(1), 558 doi:10.1029/2011MS00045.

559 Lamsal, L. N., B. N. Duncan, Y. Yoshida, N. A. Krotkov, K. E. Pickering, D. G. Streets, 560 and Z. Lu (2015), U.S. NO2 trends (2005-2013): EPA Air Quality System (AQS) data 561 versus improved observations from the Ozone Monitoring Instrument (OMI), 562 Atmospheric Environment, 110, 130-143,doi:10.1016/j.atmosenv.2015.03.055.

563 Lefohn, A.S., Shadwick, D.S. and Ziman, S.D. (1998), The difficult challenge of 564 attaining EPA's new ozone standard, Environmental Science \& Technology, 276A-282A, 5653468.

566 Lin, M., Fiore, A.M., Cooper, O.R., Horowitz, L.W., Langford, A.O., Levy, H., Johnson, 567 B.J., Naik, V., Oltmans, S.J. and Senff, C.J. (2012), Springtime high surface ozone events 568 over the western United States: Quantifying the role of stratospheric intrusions. Journal 569 of Geophysical Research: Atmospheres, 117(D21), doi:10.1029/2012JD018151.

570 Mao, J., Paulot, F., Jacob, D.J., Cohen, R.C., Crounse, J.D., Wennberg, P.O., Keller, C.A., 571 Hudman, R.C., Barkley, M.P. and Horowitz, L.W. (2013), Ozone and organic nitrates 572 over the eastern United States: Sensitivity to isoprene chemistry, Journal of Geophysical 573 Research: Atmospheres, 118(19), doi:10.1002/jgrd.50817.

574 Mcnally, D., Loomis, C., Morris, R., and Sakulyanontvittaya, T. (2009), Draft final report, 5752020 ozone source apportionment modeling for the Denver area. Available at:

576 http://ozoneaware.org/postfiles/documentsandpresentations/modeling/Draft\%20Final\%20

577 2020_OSAT_Report.pdf 
578 Ma, L.M. and Tan, Z.M. (2009), Improving the behavior of the cumulus parameterization 579 for tropical cyclone prediction: Convection trigger, Atmospheric Research, 92(2), 190-

580211.

581 Park, J.H., Guenther, A. and Helmig, D. (2013). Ozone reactivity of biogenic volatile 582 organic compound (BVOC) emissions during the Southeast Oxidant and Aerosol Study 583 (SOAS), In AGU Fall Meeting, San Francisco (pp. 9-13).

584 Pierce, T., Geron, C., Bender, L., Dennis, R., Tonnesen, G. and Guenther, A. (1998). 585 Influence of increased isoprene emissions on regional ozone modeling, Journal of 586 Geophysical Research: Atmospheres, 103(D19), pp.25611-25629.

587 Pierce, T., Geron, C., Pouliot, G., Kinnee, E. and Vukovich, J. (2002), Integration of the 588 Biogenic Emissions Inventory System (BEIS3) into the Community Multiscale Air 589 Quality (CMAQ) modeling system, in Proceedings of the AMS 4th Urban Environment 590 Symposium, Norfolk, Virginia, May 20-23, 2002. Available at:

591 http://ams.confex.com/ams/AFMAPUE/12AirPoll/abstracts/37962.htm.

592 Pinker, R.T., and Laszlo, I. (1992). Global distribution of photosynthetically active 593 radiation as observed from satellites, Journal of Climate, 5(1), 56-65.

594 Pouliot G. and Pierce, T. (2009), Integration of the Emissions of Gases and Aerosols 595 form Nature (MEGAN) into CMAQ modeling system, in 18th International Emission 596 Inventory Conference, Baltimore, Maryland, pp. 14-17.

597 Pour-Biazar, A., McNider, R.T., Roselle, S.J., Suggs, R., Jedlovec, G., Kim, S., Byun, 598 D.W., Lin, J.C., Ho, T.C., Haines, S., Dornblaser, B., Cameron, R. (2007). Correcting 599 photolysis rates on the basis of satellite observed clouds. Journal of Geophysical 600 Research, 112, D10302, doi:10.1029/2006JD007422.

601 Pour-Biazar, A., Doty, K., Park, Y.H. and McNider, R.T. (2011), Cloud assimilation into 602 the Weather and Research and Forecast (WRF) model. Submitted to Thomas C. Ho, 603 Lamar University, Prepared for Bright Dornblaser, Texas Commission on Environmental 604 Quality (TCEQ), 2011.

605 Pour-Biazar, A., McNider, R.T., White, A., Cohan, D.S., and Zhang, R. (2015), 606 Incorporating space-borne observations to improve biogenic emission estimates in Texas, 607 Submitted to Elena McDonald-Buller, Texas Commission on Environmental Quality 608 (TCEQ), AQRP 14-017, 2015.

609 Ramboll Envrion (2015), CAMx version 6.50 User's Guide. Available at: 610 http://www.camx.com/files/camxuserguide_v6-20.pgf. 
611 Reitze Jr, A.W. (2004), Air Quality Protection Using State Implementation Plans-Thirty-

612 Seven Years of Increasing Complexity, The Villanova Environmental Law Journal, 15,

613 p.209.

614 Roselle, S.J., Pierce, T.E. and Schere, K.L. (1991), The sensitivity of regional ozone

615 modeling to biogenic hydrocarbons, Journal of Geophysical Research: Atmospheres, 616 96(D4), pp.7371-7394.

617 Sakulyanontvittaya, T., G. Yarwood, and A. Guenther (2012). Improved Biogenic

618 Emission Inventories across the West Final Report. Prepared for Western Governer's

619 Association, Available at

620 http://www.wrapair2.org/pdf/WGA_BiogEmisInv_FinalReport_March20_2012.pdf

621 Shim, C., Wang, Y., Choi, Y., Palmer, P.I., Abbot, D.S. and Chance, K. (2005),

622 Constraining global isoprene emissions with Global Ozone Monitoring Experiment

623 (GOME) formaldehyde column measurements, Journal of Geophysical Research:

624 Atmospheres, 110(D24), doi:10.1029/2004JD005629.

625 Simon, H., Baker, K.R., and Phillips, S. (2012), Compilation and Interpretation of

626 Photochemical Model Performance Statistics Published Between 2006 and 2012,

627 Atmospheric Environment, 61, 124-139.

628 Simon, H., Reff, A., Wells, B., Xing, J. and Frank, N. (2014), Ozone trends across the

629 United States over a period of decreasing NOx and VOC emissions, Environmental

630 Science \& Technology, 49(1), pp.186-195.

631 Skamarock, W.C., Klemp, J.B., Dudhia, J., Gill, D.O., Barker, D.M., Duda, M.G., Huang, 632 X., Wang, W. and Powers, J.G. (2008), A description of the Advanced Research WRF

633 Version 3, In National Center for Atmospheric Research: Boulder, CO. Vol. NCAR/TN634 475+STR.

635 Stammer, D., Wentz, F.J. and Gentemann, C.L. (2003), Validation of Microwave Sea

636 Surface Temperature Measurements for Climate Purposes, Journal of Climate, 16, 73-87.

637 Wang, P., Schade, G., Estes, M., and Ying, Q. (2017). Improved MEGAN predictions of 638 biogenic isoprene in the contiguous United States. Atmospheric Environment, 148, 337639351.

640 Warneke, C., De Gouw, J.A., Del Negro, L., Brioude, J., McKeen, S., Stark, H., Kuster, 641 W.C., Goldan, P.D., Trainer, M., Fehsenfeld, F.C. and Wiedinmyer, C. (2010), Biogenic 642 emission measurement and inventories determination of biogenic emissions in the eastern 643 United States and Texas and comparison with biogenic emission inventories. Journal of 644 Geophysical Research: Atmospheres, 115(D7), doi:10.1029/2009JD012445. 
645 Yarwood, G., Gookyoung, H., Carter, W.P.L. and Whitten, G.Z. (2012), Environmental 646 Chamber Experiments to Evaluate NOX Sinks and Recycling in Atmospheric Chemical 647 Mechanisms, Final Report prepared for the Texas Air Quality Research Program, 648 University of Texas, Austin, Texas (AQRP Project 10-042).

649 Yarwood,G. and Koo B. (2015), Final Report: Improved OSAT, APCA and PSAT 650 algorithms for CAMx, Submitted to Jim Price, Texas Commission on Environmental 651 Quality (TCEQ), Contract \#582-15-50417, August 2015. Available at:

652 http://www.tceq.com/assets/public/implementation/air/am/contracts/reports/pm/58255438

653 80FY1511-20150817-improved_OSAT_APCA_PSAT_for_CAMx.pdf

654 Ying, Q., and Krishnan, A. (2010). Source contributions of volatile organic compounds to 655 ozone formation in southeast Texas. Journal of Geophysical Research: Atmospheres 656 (1984-2012), 115(D17).

657 Zhang, L., Brook, J.R., and Vet, R. (2003), A revised parameterization for gaseous dry 658 deposition in air-quality models, Atmospheric Chemistry and Physics, 3, 2067-2082.

659 Zhang, R., Suh, I., Lei, W., Clinkenbeard, A. D., \& North, S. W. (2000), Kinetic studies 660 of OH-initiated reactions of isoprene, Journal of Geophysical Research: Atmospheres 661 (1984-2012), 105(D20), 24627-24635.

662 Zhang, R., White, A., Pour-Biazar, A. Mcnider, R.T., and Cohan D.S. (2017), 663 Incorporating GOES satellite photosynthetically active radiation (PAR) retrievals to 664 improve biogenic emission estimates in Texas, Journal of Geophysical Research:

665 Atmospheres (in review). 
Table 1. Configurations of WRF-BEIS/MEGAN-CAMx modeling platform used in this study

\begin{tabular}{|c|c|c|c|}
\hline \multicolumn{4}{|c|}{ WRF } \\
\hline Version: & WRF-ARW v3.4 & Shortwave/longwave radiation: & RRTMG $^{\mathrm{a}}$ \\
\hline Domain setting: & 12km CONUS (396×246) & PBL scheme: & $\mathrm{ACM}^{\mathrm{b}}$ \\
\hline Vertical resolution: & 35 layer $\mathrm{w} / P_{\text {top }}=50 \mathrm{hPa}$ & Surface layer scheme: & Monin-Obukhov \\
\hline Land surface model: & Pleim-Xiu & Sea surface temperature (SST): & $1 \mathrm{~km}$ SST data from GHRSST ${ }^{\mathrm{c}}$ \\
\hline Microphysics: & Morris double moment & Cumulus physics: & Kain-Fritsch w/ trigger function \\
\hline Analysis nudging: & U, V, T, Q above PBL & Initial field: & 12km NAM ${ }^{\mathrm{d}}$ analysis (12NAM) \\
\hline \multicolumn{4}{|c|}{ BEIS } \\
\hline Version: & BEIS v3.14 & $\begin{array}{l}\text { Land cover and vegetation } \\
\text { speciation: }\end{array}$ & $1 \mathrm{~km} \mathrm{BELD3}{ }^{\mathrm{e}}$ for 230 land use type \\
\hline Leaf-area index: & $\begin{array}{c}2 \text { sets of vegetation species specified } \\
\text { values (summer .vs. winter) }\end{array}$ & Emission factor: & Leaf scale, land use type specified \\
\hline $\begin{array}{l}\text { Adjustment factor for } \\
\text { isoprene emission: }\end{array}$ & Temperature, light & PAR input: & $\begin{array}{l}\text { Split between direct diffused PAR based } \\
\text { on insolation input (WRF or GOES }{ }^{f} \text { ) }\end{array}$ \\
\hline \multicolumn{4}{|c|}{ MEGAN } \\
\hline Version: & MEGAN v2.1 & $\begin{array}{l}\text { Land cover and vegetation } \\
\text { speciation: }\end{array}$ & 30 sec 16 PFT types in CLM $^{g}$ \\
\hline Leaf-area index: & MODIS $^{\text {h }}$ 8-day average & Emission factor: & Canopy-scale, $1 \mathrm{~km}$ pre-gridded \\
\hline $\begin{array}{l}\text { Adjustment factor for } \\
\text { isoprene emission: }\end{array}$ & $\begin{array}{l}\text { Temperature, light, LAI, humidity, } \\
\text { wind }\end{array}$ & PAR input: & $\begin{array}{l}\text { Direct input either from WRF (half of } \\
\text { insolation) or GOES retrieval }\end{array}$ \\
\hline \multicolumn{4}{|c|}{ CAMx } \\
\hline Version: & CAMx v6.20 & Anthropogenic emission: & 2011NEIv2 ${ }^{\mathrm{i}}$ \\
\hline Boundary conditions: & GEOS-Chem & Gas-phase chemistry: & $\mathrm{CB} \mathrm{r} 2^{\mathrm{j}}$ \\
\hline Photolysis: & 2011 clear sky photolysis w/ OMI ${ }^{k}$ & Chemistry solver: & Euler-Backward Iterative (EBI) \\
\hline Dry deposition: & Zhang et al. (2003) & Vertical diffusion: & K-theory \\
\hline Vertical advection solver: & Implicit backward-Euler hybrid & Horizontal advection solver: & Pricewise Parabolic Method (PPM) \\
\hline
\end{tabular}

Note: a-The Rapid Radiative Transfer Model for GCMs; b-Asymmetrical Convective Model version 2; c-Group for High Resolution Sea Surface Temperatures; d-North American Model; e-Version 3 of the Biogenic Emissions Land use Database, f- Geostationary Operational Environmental Satellite; g-Community Land Model; h- Moderate Resolution Imaging Spectoradiometer; i-2011National

Emission Inventory version 6.2; j-Carbon Bond gaseous mechanism version 6.3 with extension; k-Ozone Measurement Instrument 
Table 2. Evaluation of GOES insolation/PAR retrieval products during May-September 2011 with available ground observations at SCAN and SURFRAD network

\begin{tabular}{c|cccccccc}
\hline & $\mathrm{N}^{\mathrm{a}}$ & $\begin{array}{c}\mathrm{OBS}^{\mathrm{b}} \\
(\mathrm{W} / \mathrm{m} 2)\end{array}$ & $\begin{array}{c}\mathrm{SIM}^{\mathrm{c}} \\
(\mathrm{W} / \mathrm{m} 2)\end{array}$ & $\mathrm{R}^{\mathrm{d}}$ & $\begin{array}{c}\mathrm{RMSE}^{\mathrm{e}} \\
(\mathrm{W} / \mathrm{m} 2)\end{array}$ & $\begin{array}{c}\mathrm{MB}^{\mathrm{f}} \\
(\mathrm{W} / \mathrm{m} 2)\end{array}$ & NMB $^{\mathrm{g}}$ & $\mathrm{NME}^{\mathrm{h}}$ \\
\hline GOES_insolation & 67823 & 243 & 265 & 0.96 & 108 & 13 & $7 \%$ & $26 \%$ \\
WRF_insolation & 67823 & 243 & 289 & 0.91 & 144 & 47 & $19 \%$ & $31 \%$ \\
GOES_PAR & 12758 & 104 & 113 & 0.94 & 40 & 9 & $9 \%$ & $22 \%$ \\
WRF_PAR & 12758 & 104 & 130 & 0.92 & 62 & 25 & $24 \%$ & $35 \%$ \\
\hline
\end{tabular}

Note: a-total observation records; b-mean observation; c-mean simulation; d-correlation coefficient; e-root mean square error; f-mean bias; g-normalized mean bias; h-normalized mean error 
Table 3 Statistics for CAMx performance relative to ground-level observations of hourly isoprene, nitrogen dioxide ( $\left.\mathrm{NO}_{2}\right)$, and maximum daily 8 hour ozone (MDA8) at AQS network sites during summer of 2011 for the three biogenic emissions cases.

\begin{tabular}{|c|c|c|c|c|c|c|c|c|c|c|c|c|c|c|}
\hline & \multirow[b]{2}{*}{ sites } & & \multicolumn{4}{|c|}{ BEIS_WRF } & \multicolumn{4}{|c|}{ BEIS_GOES } & \multicolumn{4}{|c|}{ MEGAN_GOES } \\
\hline & & $\begin{array}{c}\mathrm{OBS}^{\mathrm{a}} \\
(\mathrm{ppbV})\end{array}$ & $\begin{array}{c}\mathrm{SIM}^{\mathrm{b}} \\
(\mathrm{ppbV})\end{array}$ & $\mathrm{R}^{\mathrm{C}}$ & $\begin{array}{c}\mathrm{NMB}^{\mathrm{d}} \\
(\%) \\
\end{array}$ & $\begin{array}{l}\mathrm{NME}^{\mathrm{e}} \\
(\%)\end{array}$ & $\begin{array}{c}\text { SIM } \\
(\mathrm{ppbV})\end{array}$ & $\mathrm{R}$ & $\begin{array}{c}\text { NMB } \\
(\%)\end{array}$ & $\begin{array}{c}\text { NME } \\
(\%)\end{array}$ & $\begin{array}{c}\text { SIM } \\
\text { (ppbV) }\end{array}$ & $\mathrm{R}$ & $\begin{array}{c}\text { NMB } \\
(\%)\end{array}$ & $\begin{array}{c}\text { NME } \\
(\%)\end{array}$ \\
\hline \multirow{6}{*}{\begin{tabular}{l}
$\overline{0}$ \\
\multirow{0}{0}{} \\
0 \\
0
\end{tabular}} & ${\text { CENRAP }(68)^{f}}^{f}$ & 0.24 & 0.43 & 0.38 & $76 \%$ & $144 \%$ & 0.44 & 0.38 & $79 \%$ & $141 \%$ & 1.23 & 0.51 & $404 \%$ & $416 \%$ \\
\hline & $\mathrm{LADCO}(4)$ & 0.36 & 0.33 & 0.54 & $-8 \%$ & $76 \%$ & 0.35 & 0.58 & $-3 \%$ & $76 \%$ & 0.54 & 0.54 & $50 \%$ & $104 \%$ \\
\hline & MANE-VU(26) & 0.52 & 0.55 & 0.42 & $7 \%$ & $90 \%$ & 0.54 & 0.4 & $5 \%$ & $87 \%$ & 1.5 & 0.46 & $189 \%$ & $223 \%$ \\
\hline & VISTAS(12) & 2.14 & 1.59 & 0.39 & $-26 \%$ & $65 \%$ & 1.66 & 0.45 & $-22 \%$ & $62 \%$ & 4.59 & 0.48 & $114 \%$ & $138 \%$ \\
\hline & WRAP(32) & 0.1 & 0.19 & 0.3 & $90 \%$ & $170 \%$ & 0.18 & 0.37 & $87 \%$ & $156 \%$ & 0.49 & 0.44 & $401 \%$ & $431 \%$ \\
\hline & US_average & 0.67 & 0.62 & 0.41 & $28 \%$ & $109 \%$ & 0.63 & 0.44 & $29 \%$ & $104 \%$ & 1.67 & 0.49 & $232 \%$ & $262 \%$ \\
\hline \multirow{6}{*}{ 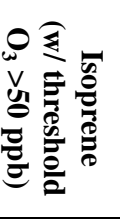 } & CENRAP(58) & 0.38 & 0.76 & 0.3 & $113 \%$ & $173 \%$ & 0.63 & 0.33 & $79 \%$ & $140 \%$ & 1.89 & 0.48 & $404 \%$ & $413 \%$ \\
\hline & $\operatorname{LADCO}(3)$ & 1.04 & 0.98 & 0.33 & $-8 \%$ & $63 \%$ & 0.82 & 0.38 & $-21 \%$ & $65 \%$ & 1.26 & 0.38 & $22 \%$ & $76 \%$ \\
\hline & MANE-VU(25) & 0.9 & 1.1 & 0.35 & $20 \%$ & $92 \%$ & 0.95 & 0.33 & $1 \%$ & $84 \%$ & 2.51 & 0.41 & $179 \%$ & $211 \%$ \\
\hline & VISTAS(11) & 2.92 & 2.51 & 0.27 & $-15 \%$ & $60 \%$ & 2.26 & 0.41 & $-24 \%$ & $56 \%$ & 5.87 & 0.45 & $101 \%$ & $117 \%$ \\
\hline & WRAP(29) & 0.26 & 0.48 & 0.1 & $78 \%$ & $155 \%$ & 0.44 & 0.22 & $60 \%$ & $130 \%$ & 1.1 & 0.32 & $317 \%$ & $338 \%$ \\
\hline & US_average & 0.81 & 1.03 & 0.46 & $28 \%$ & $99 \%$ & 0.89 & 0.51 & $10 \%$ & $86 \%$ & 2.45 & 0.56 & $202 \%$ & $222 \%$ \\
\hline \multirow{6}{*}{ oz } & CENRAP(71) & 7.5 & 9.4 & 0.49 & $26 \%$ & $79 \%$ & 9.1 & 0.49 & $22 \%$ & $77 \%$ & 9.4 & 0.49 & $26 \%$ & $79 \%$ \\
\hline & LADCO(22) & 12.2 & 14.4 & 0.59 & $18 \%$ & $68 \%$ & 14 & 0.59 & $15 \%$ & $67 \%$ & 14.4 & 0.59 & $18 \%$ & $69 \%$ \\
\hline & MANE-VU(55) & 11.2 & 10.2 & 0.44 & $-9 \%$ & $66 \%$ & 9.9 & 0.44 & $-12 \%$ & $65 \%$ & 10.2 & 0.44 & $-9 \%$ & $66 \%$ \\
\hline & VISTAS(31) & 7.3 & 10.3 & 0.39 & $41 \%$ & $94 \%$ & 10.1 & 0.39 & $38 \%$ & $93 \%$ & 10.3 & 0.39 & $41 \%$ & $94 \%$ \\
\hline & WRAP(171) & 8.4 & 7.3 & 0.48 & $-14 \%$ & $70 \%$ & 7 & 0.48 & $-17 \%$ & $70 \%$ & 7.3 & 0.48 & $-13 \%$ & $70 \%$ \\
\hline & US_average & 9.3 & 10.3 & 0.48 & $12 \%$ & $75 \%$ & 10.0 & 0.48 & $9 \%$ & $74 \%$ & 10.3 & 0.48 & $13 \%$ & $76 \%$ \\
\hline \multirow{6}{*}{ 异罪 } & CENRAP(191) & 48.4 & 53.8 & 0.67 & $11 \%$ & $20 \%$ & 53.2 & 0.68 & $10 \%$ & $19 \%$ & 53.7 & 0.63 & $11 \%$ & $21 \%$ \\
\hline & LADCO(209) & 45.5 & 49.4 & 0.79 & $9 \%$ & $16 \%$ & 49.7 & 0.79 & $7 \%$ & $16 \%$ & 49.7 & 0.8 & $9 \%$ & $17 \%$ \\
\hline & MANE-VU(201) & 44.5 & 49.7 & 0.82 & $12 \%$ & $18 \%$ & 50.4 & 0.82 & $10 \%$ & $17 \%$ & 50.4 & 0.82 & $13 \%$ & $19 \%$ \\
\hline & VISTAS(276) & 47 & 56.7 & 0.75 & $21 \%$ & $23 \%$ & 56.5 & 0.75 & $19 \%$ & $22 \%$ & 56.5 & 0.74 & $20 \%$ & $23 \%$ \\
\hline & WRAP(438) & 51.2 & 52.9 & 0.70 & $17 \%$ & $16 \%$ & 51.7 & 0.70 & $15 \%$ & $15 \%$ & 51.7 & 0.70 & $1 \%$ & $3 \%$ \\
\hline & US_average & 47.3 & 52.5 & 0.75 & $14 \%$ & $19 \%$ & 52.4 & 0.75 & $12 \%$ & $18 \%$ & 52.4 & 0.74 & $11 \%$ & $17 \%$ \\
\hline \multirow{6}{*}{ 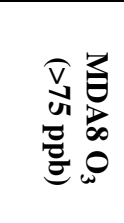 } & CENRAP(153) & 81.4 & 72.2 & 0.27 & $-11 \%$ & $14 \%$ & 72 & 0.26 & $-11 \%$ & $14 \%$ & 73.7 & 0.3 & $-9 \%$ & $14 \%$ \\
\hline & LADCO(164) & 80.7 & 75.5 & 0.35 & $-6 \%$ & $11 \%$ & 74.6 & 0.35 & $-8 \%$ & $11 \%$ & 80.7 & 0.38 & $0 \%$ & $11 \%$ \\
\hline & MANE-VU(143) & 82.2 & 83 & 0.33 & $1 \%$ & $10 \%$ & 80.8 & 0.32 & $-2 \%$ & $10 \%$ & 88.6 & 0.36 & $8 \%$ & $14 \%$ \\
\hline & VISTAS(160) & 80 & 79.5 & 0.27 & $-1 \%$ & $10 \%$ & 78.4 & 0.26 & $-2 \%$ & $10 \%$ & 82.4 & 0.32 & $3 \%$ & $12 \%$ \\
\hline & WRAP(217) & 82.8 & 69.7 & 0.35 & $-16 \%$ & $17 \%$ & 69.3 & 0.32 & $-16 \%$ & $17 \%$ & 69.7 & 0.42 & $-16 \%$ & $18 \%$ \\
\hline & US_average & 81.9 & 73.6 & 0.32 & $-10 \%$ & $14 \%$ & 72.9 & 0.31 & $-11 \%$ & $14 \%$ & 75.5 & 0.37 & $-8 \%$ & $15 \%$ \\
\hline
\end{tabular}

Note: a-mean observation; b-mean simulation; c-correlation coefficient; d-normalized mean bias; e-normalized mean error; f-the numbers in the parentheses denote total observation sites used in that region to do the model performance evaluation 


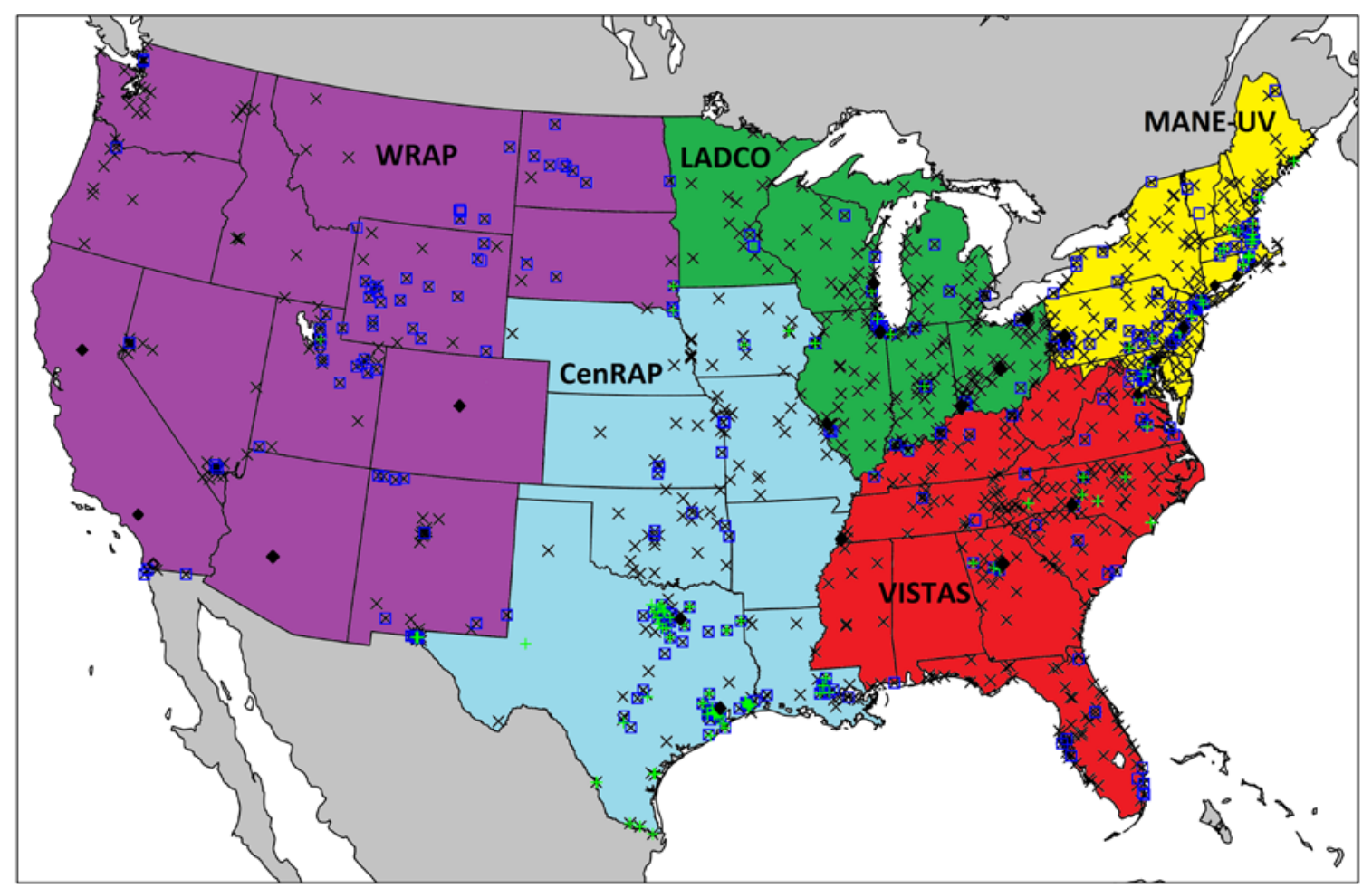

Figure 1. Source regions for ozone source apportionment analysis and the AQS site locations for NO2 (blue square), ozone (black cross ' $x$ ') and isoprene (green plus '+') for model performance evaluation as well as the site locations with the highest ozone design value for nonattainment areas in 2011 (solid black diamond; see Table S1). 

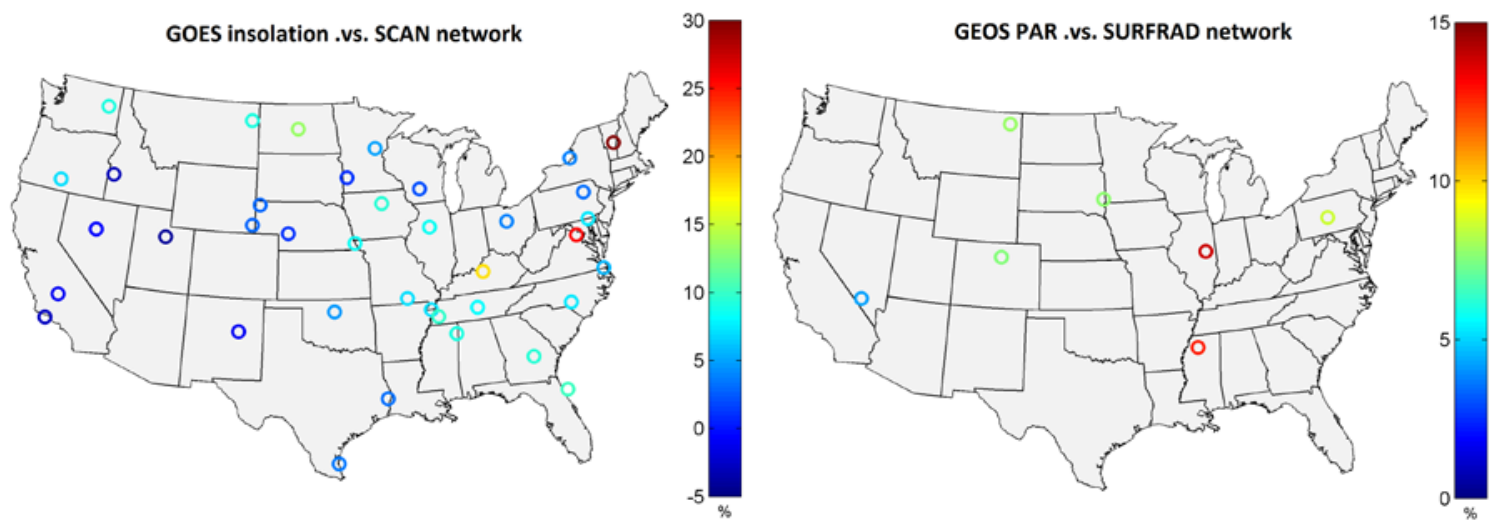

Figure 2. Performance of GOES insolation retrievals (left) and GOES PAR retrievals (right) evaluated with corresponding ground pyranometer measurements in terms of average normalized mean bias (NMB) during May-September 2011. 

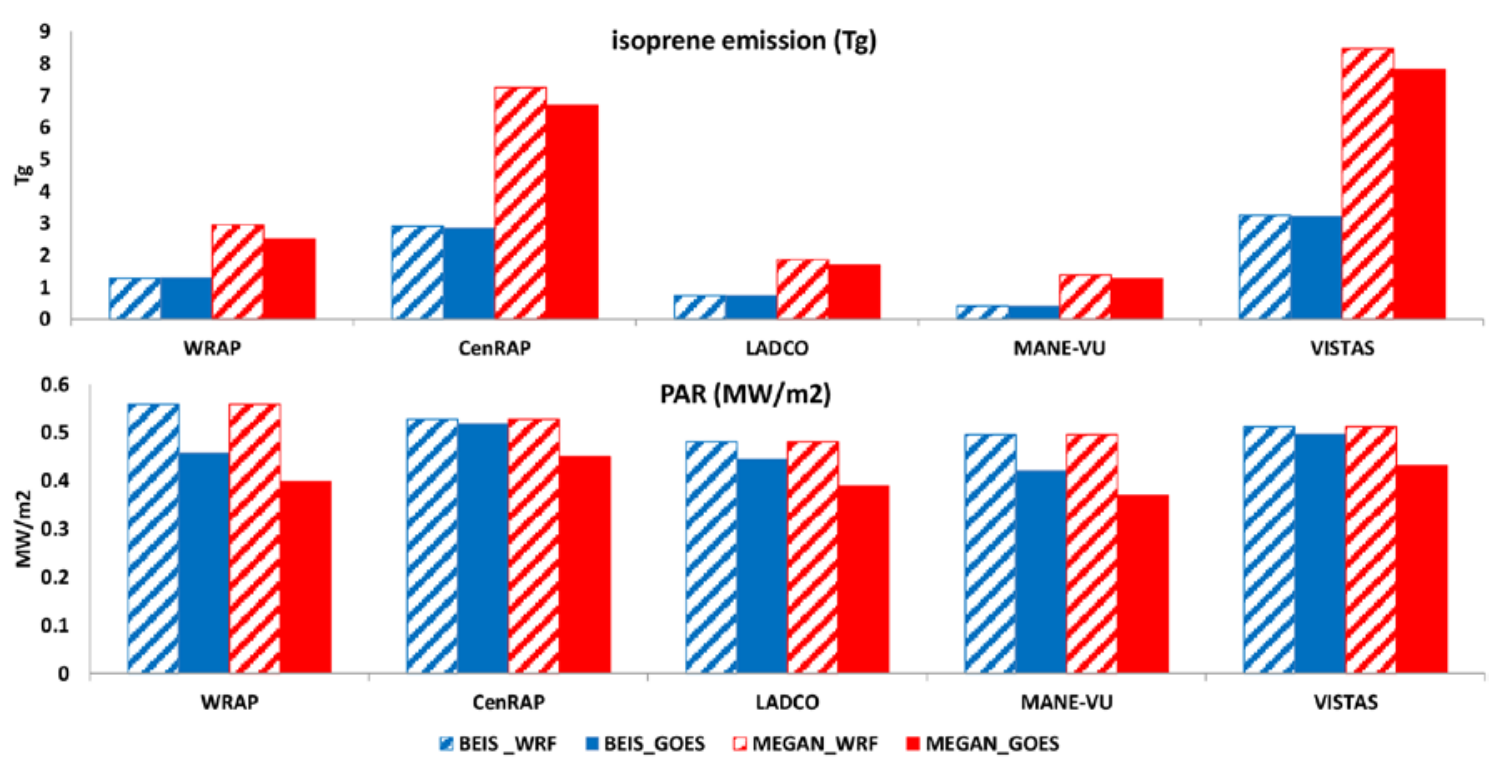

Figure 3. Estimated isoprene emissions (top) and available PAR (bottom) at different regions in the 12US2 domain using BEIS or MEGAN biogenic emission models with GOES or WRF insolation/PAR data during May-September 2011. 

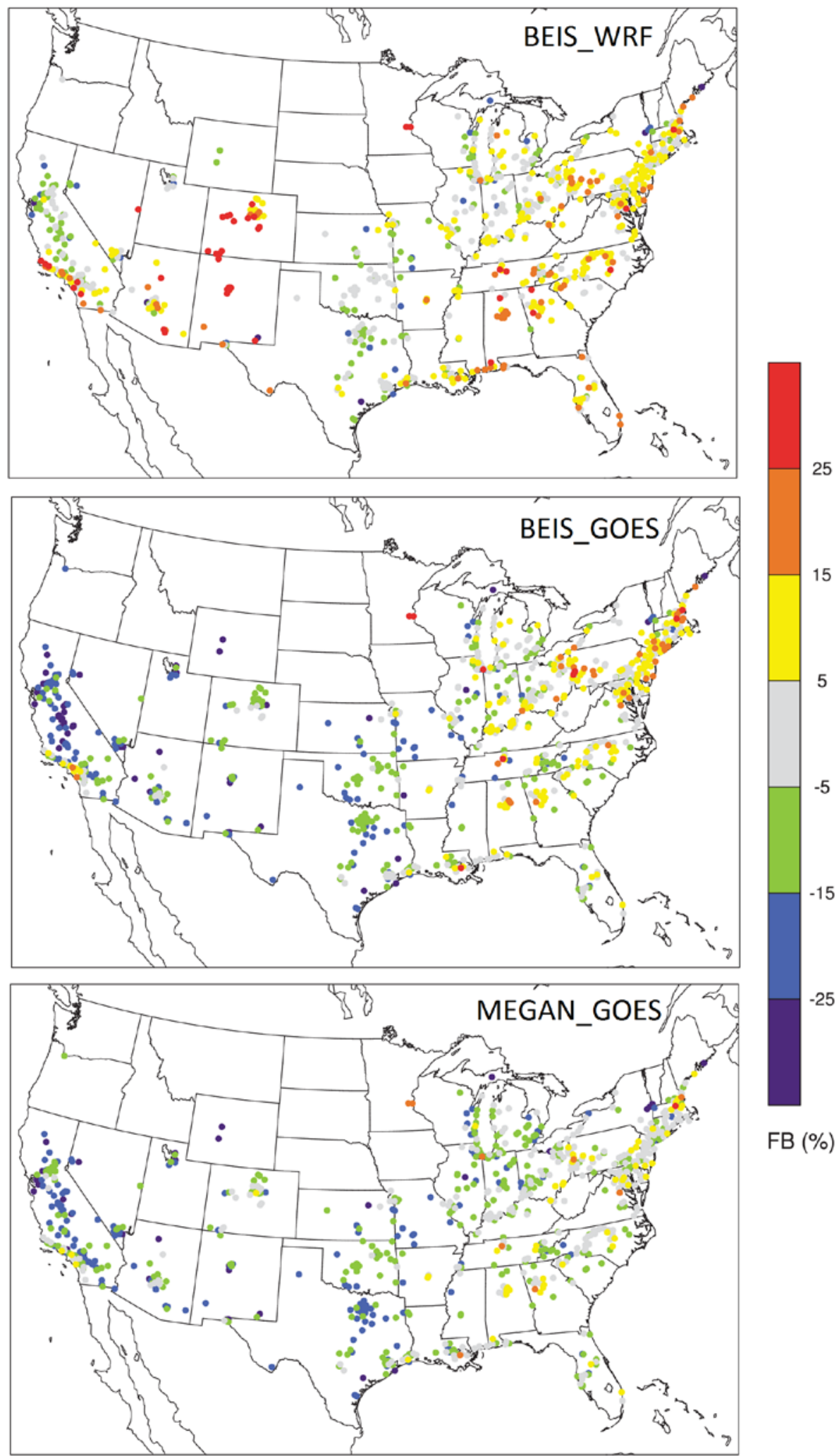

Figure 4. Fractional bias (FB) of simulated maximum daily 8-hr ozone (MDA8) relative to observations when observed MDA8 ozone exceeds $75 \mathrm{ppbV}$ at AQS monitors. 


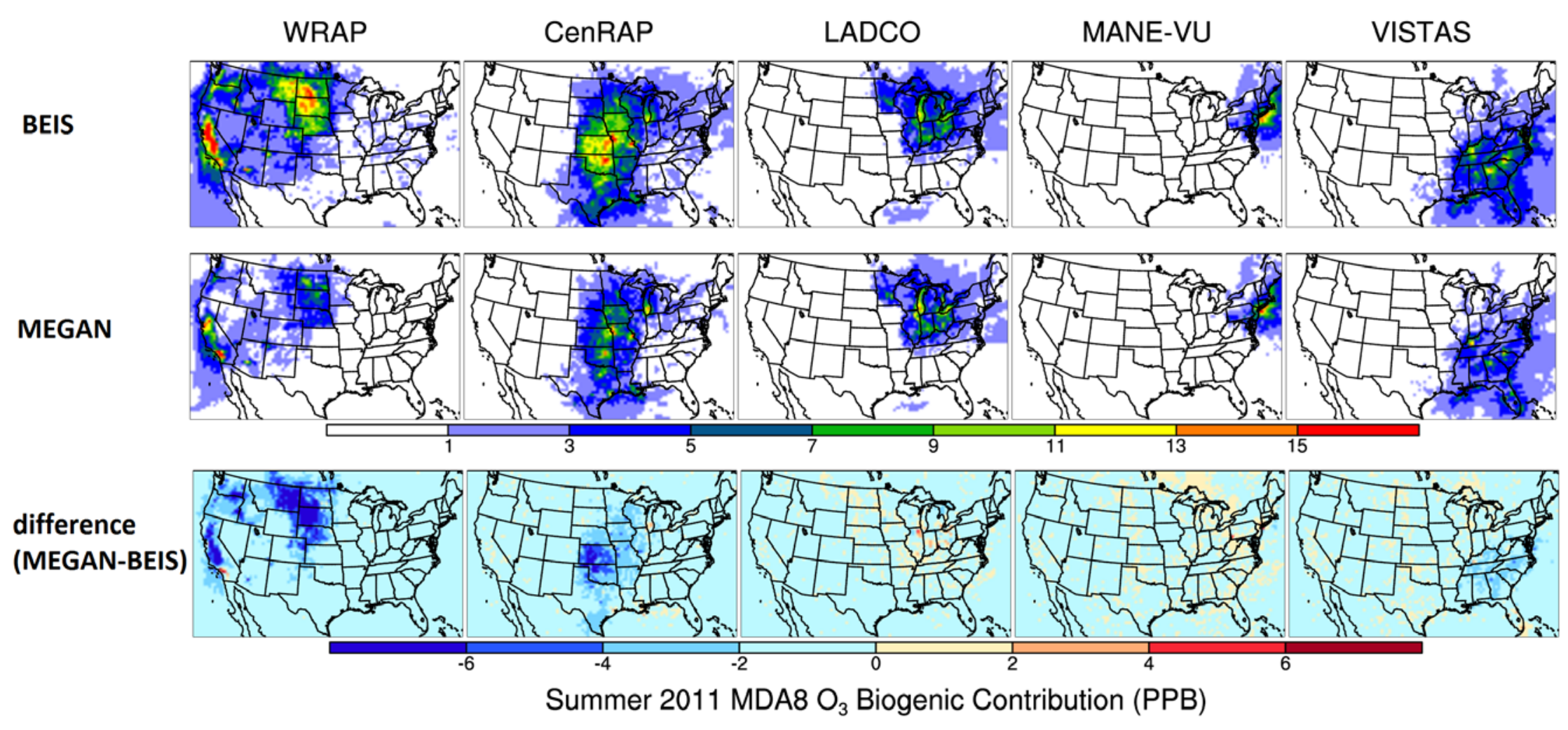

Figure 5. OSAT modeled contributions of biogenic sources from each source region to MDA8 ozone, averaged over May-September 2011 under the BEIS and MEGAN BVOC emission cases. 


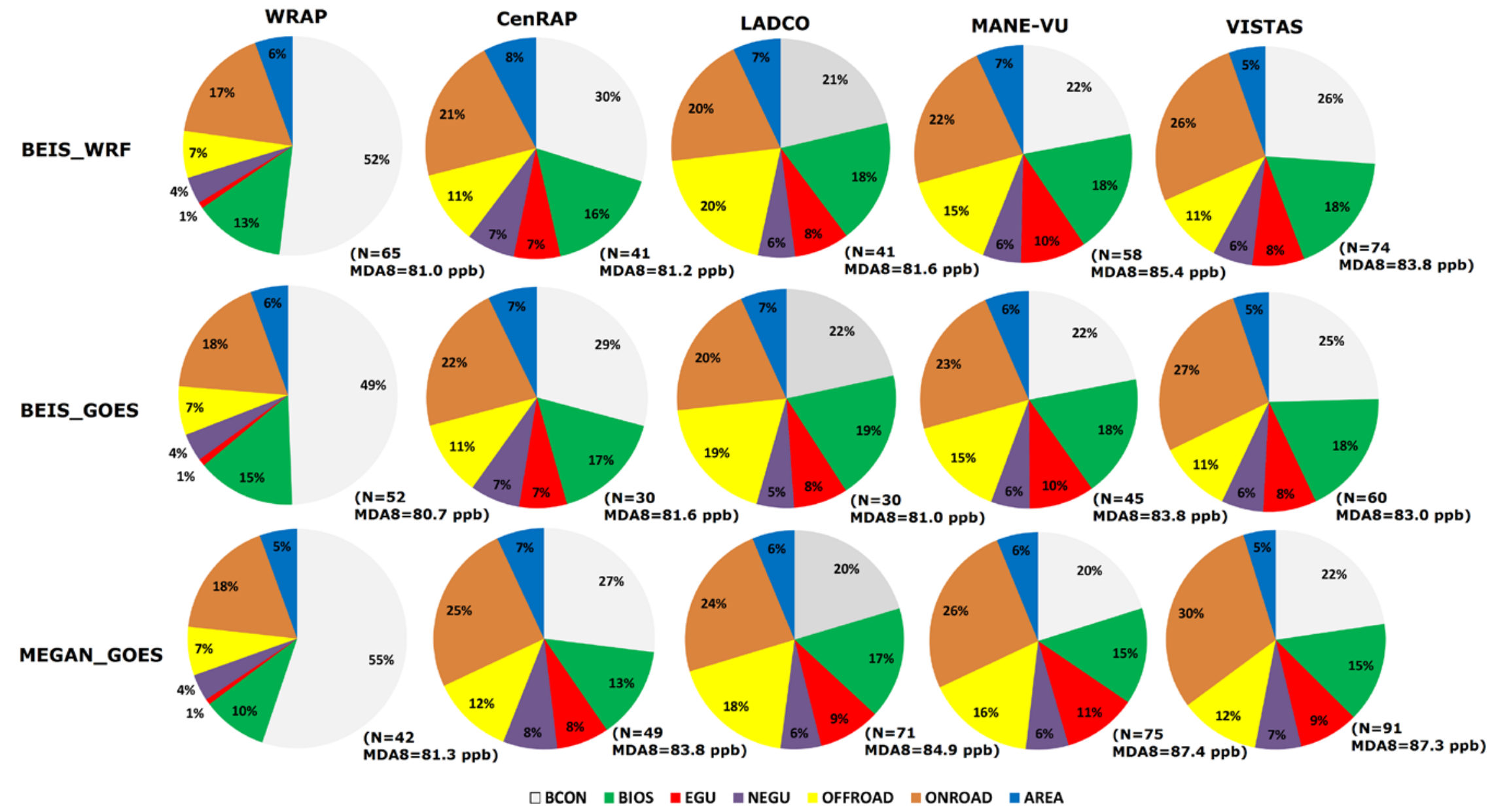

Figure 6. Average OSAT source contributions of 6 emission sectors and boundary conditions (BCON) to MDA8 ozone at nonattainment receptor sites in 5 U.S. regions under the three biogenic VOC emissions cases. 

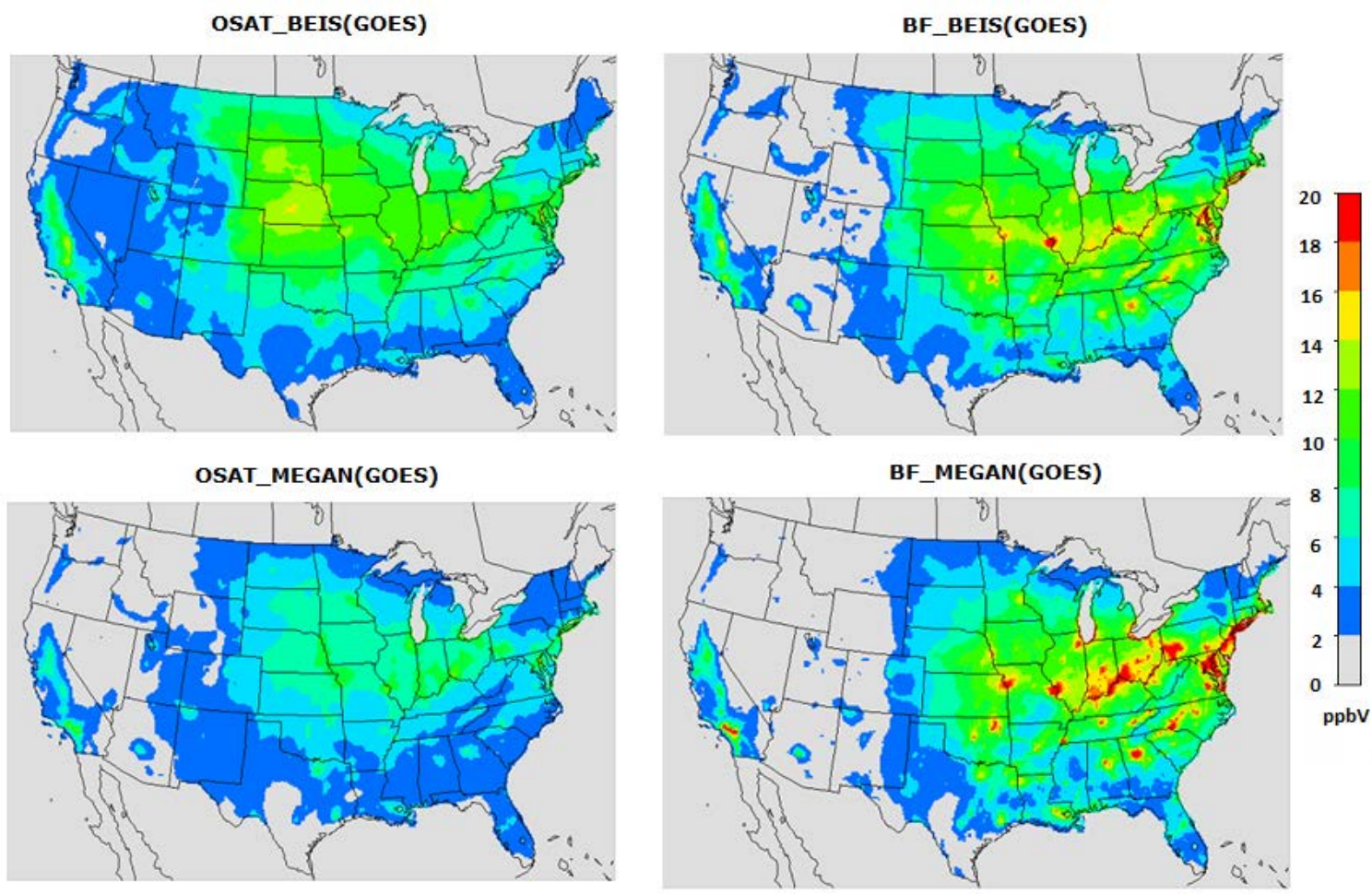

Figure 7. OSAT (left) and brute force zero-out (right) source apportionment of MDA8 ozone during summer 2011 to biogenic VOC sources from BEIS (top) and MEGAN (bottom), each with GOES satellite insolation. 

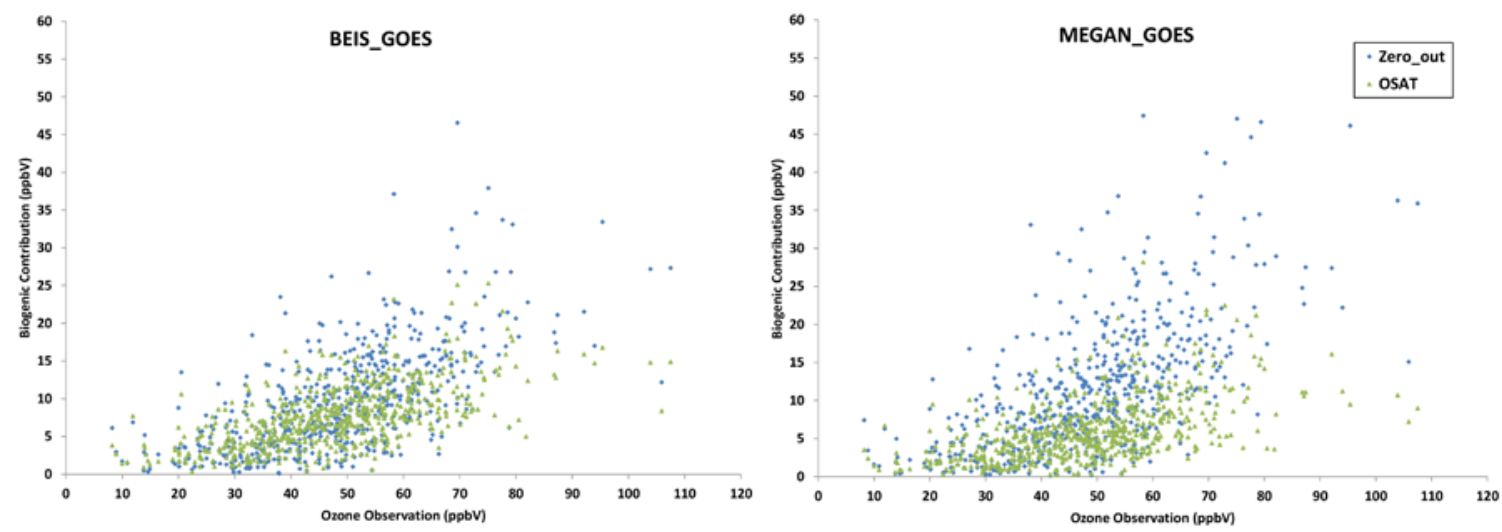

Figure 8. Comparison of biogenic VOC contribution to ozone at nonattainment sites as attributed by OSAT (green triangles) and zero-out (blue diamonds) methods, for the case with BEIS (left) and MEGAN (right) emissions and satellite-retrieved insolation. 